\title{
Chemopreventive Effect of Hibiscus sabdariffa Calyx Anthocyanins and Nanoselenium against $N$-Diethylnitrosamine-Induced Hepatocellular Carcinoma in Rats
}

\author{
Adam O. Abaker ${ }^{1 *}$, Eman N. Aly ${ }^{2}$, Eman I. Kandil ${ }^{1}$ and Kamal F. Shalaby ${ }^{1}$ \\ ${ }^{I}$ Department of Biochemistry, Faculty of Science, Ain Shams University, Cairo, Egypt, \\ ${ }^{2}$ National Center for Radiation Research and Technology, Atomic Energy Authority, Cairo, Egypt
}

\section{ARTICLE INFO}

Article history:

Received 10 September 2015

Accepted 19 October 2015

Keywords:

Hepatocellular carcinoma;

Nanoselenium;

Hibiscus;

Anthocyanin;

Antioxidant.

\begin{abstract}
A B S T R A C T
Chemoprevention could play important role in the management of Hepatocellular carcinoma (HCC). HCC develop in pre-neoplastic organ, the cirrhotic liver. The study aimed at evaluating the efficacy of Hibiscus sabdariffa L. water extract containing anthocyanins and Nanoselenium (nSe) as chemo-protective substances on HCC induced by Diethylnitrosamine (DEN). Thioacetamide (TAA) which causes liver cirrhosis was used as initiator. The oxidative stress marker malondialdehyde (MDA) level for lipid peroxidation, liver antioxidant enzymes, superoxide dismutase (SOD) and catalase (CAT) activities as well as reduced glutathione (GSH) content were measured, in addition, to Alpha fetoprotein (AFP), tumor necrosis factor (TNF- $\alpha$ ) and caspase-3 levels. Treatment by $H$. sabdariffa extract significantly increase caspase- 3 activity and decrease both TNF- $\alpha$ and AFP levels; significantly decrease the oxidative stress marker MDA level and increase the level of antioxidant markers SOD, CAT and GSH. The plant extract showed a remarkable effect as selenium which is known by its significant antioxidant effect. The findings were well depicted histopathologically. It can be concluded that HEx containing anthocyanin pigments and nSe can act strongly as chemo-protective substances against HCC, possibly by increasing apoptotic mechanism and antioxidant scavenger levels.
\end{abstract}

\section{Introduction}

Hepatocellular carcinoma (HCC) is an environmentally related cancer, with both hepatitis viruses (HBV or $\mathrm{HCV}$ ) and chemical carcinogens involved in a multistage process. The incidence of HCC increases in cirrhotic patients who have undergone curative treatment for primary HCC ${ }^{[1,2]}$. HCC is the most common cancers globally and is a major problem in male in Egypt ${ }^{[3]}$. Hepatitis B virus (HBV) is the major leading cause of HCC in Egypt ${ }^{[4]}$. Hepatitis C virus (HCV) has become the predominant factor associated with the more epidemic; thereby the highest prevalence rate of $\mathrm{HCV}$ infection worldwide is established in this important country, Egypt ${ }^{[5]}$. Hifnawy, et al. ${ }^{[6]}$ reported other cause of the infection that is etiological role for aflatoxin B1, but Abdel-Wahab, et al. ${ }^{[7]}$ referred the prevalence of HCC in the Nile Delta region to pollution due to insecticides as risk factor, interpreting that by the

\footnotetext{
* Corresponding author.

E-mail address: ad22m@yahoo.com
}

common HCC infection in males whom represent the majority dealer with this material in the farm. El-Zayadi, et $\boldsymbol{a l} .{ }^{[8]}$ adds another risk factor that increasing survival rate among patients with cirrhosis lead to develop HCC. Due to high incidence of HCC developed from cirrhotic Egyptian which reach nearly $21 \%$ an active surveillance and secondary prevention programs for patients with chronic hepatitis are the most important steps to reduce the risk of $\mathrm{HCC}^{[9]}$.

Chemotherapy continues to be the mainstay treatment of cancer, beside surgery and radiotherapy ${ }^{[10]}$. Synergetic chemo-radiotherapy in cancer treatment has sort of advantage, but distant metastases remain the predominant site effect of treatment failure [11]. Therefore, there is an ongoing search for better controlling and preventive methods in order to reduce cancer mortality and related side effects. Many investigations are now being carried out to discover naturally occurring compounds that can suppress or prevent the process of carcinogenesis ${ }^{[12,13]}$. 
Biological response modifiers (BRMs) are compounds that have a unique effect on physiological functions and can diminish the side effects of cancer treatments while increasing their efficiency ${ }^{[14]}$. The chemoprevention characteristics of number of plants are still being actively investigated and some have predicted promising results in cancer prevention ${ }^{[15]}$. One of the striking plants in this manner is a medicinal herb Hibiscus sabdariffa L. (family Malvaceae), the commonly name in English Roselle or red sorrel, and in Arabic Karkadeh, it is widely grown in Central and West Africa, South Asia and elsewhere ${ }^{[16]}$. The commercially important part of the plant is the fleshy calyx (sepals), whole plant can be used as beverage, or the dried calyces can be soaked in water to prepare a colorful cold drink, or may be boiled in water and taken as a hot drink ${ }^{[17]}$.

Anthocyanins as, flavanols that present in herbs are well known to be strong anti-oxidants and possess a variety of anti-cancer effects, such as cell growth arrest, kinase activity inhibition, induction of apoptosis, suppression of matrix metalo-proteinases secretion and reduction in tumor invasive behavior. Roselle is rich in anthocyanins and protocatechuic acid (PCA). The Hibiscus sabdariffa extract consider to be save that the $\mathrm{LD}_{50}$ of roselle calyx extract was found to be above $5000 \mathrm{mg} \mathrm{kg}^{-1[18]}$.

Selenium is a necessary trace element for human body. Selenium nanoparticles possess superiority photoelectric performance and higher biological activity ${ }^{[19]}$. It is an essential micronutrient at low concentration, but toxic in elevated level ${ }^{[20]}$. Human body uses selenium to produce seleno-proteins such as glutathione peroxidase (GPx) which protects liver cells against mitochondrial swelling ${ }^{[21]}$.

Both oxidative and reductive stress can trigger redox cascades that bring about changes in the thiol status of the cell. Oxidative stress develops as an imbalance between the productions of reactive oxygen species (ROS) and the antioxidant defense ${ }^{[22]}$. Dietary selenium (at least $1 \mu \mathrm{g} \mathrm{Se} / \mathrm{g}$ of diet) has been shown to reduce aflatoxin $\mathrm{B}_{1}$-induced pre-neoplastic hepatic lesions in rats ${ }^{[23,24]}$, only when it was given during the initiation stage of carcinogenesis. The enzymes that may play roles in inhibiting cancer initiation comprise glutathione peroxidase (GPx) and thioredoxinreductase (TR) and both enzymes are Se-dependent enzymes. Accordingly Se deprivation will increase tumorogenesis expectation due to the important metabolic roles of these selenoproteins in the body ${ }^{[24]}$.

Toxicity of selenium is mainly thought to be due to its ability to catalyze the oxidation of thiols and simultaneous generation of superoxide that can damage cellular components ${ }^{[25]}$. Use of selenium in chemoprevention requires that the element to be considered as a pharmacological agent, whose clinical utility may require long-term administration at supranutritional levels, in which case the safety margin and potential toxic effects of selenium are important considerations ${ }^{[26]}$. Elemental selenium at nano size (nSe) has comparable efficacy to selenite in up regulat- ing seleno-enzymes and tissue selenium levels, but is less toxic ${ }^{[27,28]}$.

In this study, $H$. sabdariffa aqueous extracted anthocyanins and nanoselenium were conducted in comparison manner to evaluate their efficacy as chemopreventive agents for HCC induced by $\mathrm{N}$ diethylnitrosamine.

\section{Materials and Methods}

\section{Experimental Animals}

Ninety Female Wister Swiss albino rats with initial weight of 115-130 g were used in the present study. The animals were purchased from the breeding unit of National Cancer Institute (NCI), Cairo University; Cairo, Egypt. The rats were housed 7 or 8 animals per cage in normal environmental and nutritional conditions, and received cubic foods and tap water ad libitum throughout the period of study. The animals were acclimatized to laboratory condition for two weeks.

\section{Chemicals and study materials}

$N$-diethylnitrosamine (DEN) and Selenium Nano-powder were purchased from Sigma, Germany. Thioacetamide (TAA) was purchased by Al-Gumhoria chemical Company, Cairo-Egypt. All assay kits for antioxidant, liver function, kidney function, lipid profile, tumor markers were purchased by Bio-Diagnostic, Egypt, BioSystem, Spain, and AssyPro, USA. All other chemicals were of analytical grade.

The drug, Hibiscus sabdariffa L. dried calyces were purchased by local market distributer in downtown Attaba- Cairo, Egypt. The drug Selenium Nano-powder (nSe) 100 mesh, was purchased from Sigma, Germany.

Preparation of anthocyanins extract and nanoselenium

Karkadeh (H. sabdariffa)-extract (containing anthocyanins) was prepared according to Builders, et al. ${ }^{[29]}$ with modification, in brief, two kilograms $(2 \mathrm{~kg})$ of the plant calyces were washed by 8 liters distilled water from any dirty, then extracted by $4 \mathrm{~L}$ of distilled water $\left(80-90^{\circ} \mathrm{C}\right)$, left to evaporate till reached one liter volume, the extract lyophilized in freeze dryer (Edwards 5399, Buch \& Holm A/S) Central laboratory, Ain Shams University. The powdered extract (HEx) was used to prepare the appropriate concentrations.

Nanoselenium was prepared in nano-form by grinding in energy Ball Mill. The observation of the particle shape and the measurement of the particle size distribution of the precipitate were performed using a JSM-5200 Transmission Electron Microscope (JEOL, Japan), National Research Center, Cairo, Egypt.

Then nanoselenium was dissolved by $10 \%$ dimethyl sulfoxide (DMSO) Sigma, and the homogenous solution completed by normal saline to the selected concentration, heated-stirring to approximately $80^{\circ} \mathrm{C}$ for one hour, homogenous nanoselenium solution, remain settled for hours where injected i.p. to the animals according to Henriquez, et al. ${ }^{[30]}$ who dissolved elemental selenium in DMSO but at high temperature $\left(\sim 150^{\circ} \mathrm{C}\right)$ in the presence of zinc. 


\section{Experimental design}

The animals were divided randomly into 6 groups, each of 15 animals as follow:

Group 1: Normal untreated serve as normal healthy control.

Group 2: Supplied orally by Hibiscus extract (HEx).

Group 3: i.p. injected by nanoselenium (nSe).

Group 4: i.p. injected by $N$-diethylnitrosamine (DEN).

Group 5: treated by HEx during injection by DEN.

Group 6: i.p. injected by nSe during injection by DEN.

HEx was supplied orally $250 \mathrm{mg} / \mathrm{Kg}$ body weight (b.w.) thrice/week for 6 months; $2 \mathrm{mg} / \mathrm{Kg}$ b.w. of $\mathrm{nSe}$ was injected twice/week for 6 months. $45 \mathrm{mg} / \mathrm{Kg}$ b.w of DEN was injected once/month for 5 months the animals received additional dose in the last month according to klaunig, et al. ${ }^{[31]}$ with modification comprises initial injection i.p. by Thioacetamide (TAA) $50 \mathrm{mg} / \mathrm{Kg}$ b.w. twice/month until the end of the experiment started two weeks before DEN injection according to Dragan, et al. ${ }^{[32]}$. DEN and TAA were dissolved by normal saline to prepare the selected concentrations of each. The concentration is prepare as $\mathrm{mg} / \mathrm{ml}$ in total volume of $0.5 \mathrm{ml}$ injected intraperitoneally to the rats by insulin syringe. The weight of the animals, and the number of mortality, were recorded weekly.

Six animals from each group were scarified after 4 months from the beginning of the experiment in a trial to examine carcinogenicity occurrence and the progress of the experiment.

\section{Experimental Protocol}

After the end of the experiment time, the animals were anesthetized by diethyl ether, and then scarified by cervical dislocation. The blood was collected from the heart by heparinized syringe to heparinized tubes, and centrifuged at $3000 \mathrm{rpm}$ for 10 minutes. The plasma stored at $-20{ }^{\circ} \mathrm{C}$ for further investigation. Slices of the livers were excised and placed in $10 \%$ formalin for histopathology study. Whereas the rest of the livers were stored at $-80^{\circ} \mathrm{C}$ to prepare $10 \%$ of liver homogenate and lysate for further investigations.

\section{Biochemical Assays}

Aspartate aminotransferase (AST) and Alanine aminotransferase (ALT) activities in plasma were determined by colorimetric method described by Reitman and Frankel ${ }^{[33]}$ using diagnostic kit. Biuret colorimetric method was applied to determine total protein concentration in plasma according to Gornal, et al. ${ }^{[34]}$ using diagnostic kit. Albumin concentration in the plasma samples were determined by colorimetric method using diagnostic kit supplied by Biodiagnostic as described by Doumas, et al. ${ }^{[35]}$. Creatinine concentration in the sample was determined according to Barties, et al. ${ }^{[36]}$ by kinetic methods using diagnostic kit.Urea in plasma was determined colorimetrically as described by Fawcett and Soctt ${ }^{[37]}$, using a diagnostic kit.

The level of lipid peroxidation was estimated as malondialdehyde (MDA), the end product of lipid per- oxidation by the method described by Yoshioka, et al. ${ }^{[38]}$. Reduced glutathione (GSH) was measured in whole blood according to Beutler, et al. ${ }^{[39]}$. The activities of antioxidant enzymes, superoxide dismutase (SOD) were measured according to Minami and Yoshikawa ${ }^{[40]}$, and catalase (CAT) activity was determined according to Sinha ${ }^{[41]}$.

Caspase-3 in liver cells lysate was quantitatively determined by colorimetric detection kit the method of detection was modified by Tonner et al. ${ }^{[42]}$. TNF-alpha concentration was carried out by The Assay Max Rat TNF-alpha ELISA kit as described by the manufacture. Alpha-Fetoprotein (AFP) was determined according to the method of Hirai ${ }^{[43]}$.

\section{Histopathological Study}

Specimens of liver tissues were fixed in $10 \%$ buffered neutral formalin solution, embedded in paraffin and fivemicron thick paraffin sections were fixed on slides. Slides were then stained with hematoxylin and eosin "HE", according to Banchroft, et al. ${ }^{[44]}$, examined and photographed.

\section{Statistical Analysis}

Statistical analysis was carried out to compare between different groups by one way ANOVA using SPSS (Statistical Package for Social Science, version 15). The significance among the groups was compared at $p<0.05$ $=$ significant, and $p<0.001=$ highly significant.

\section{Results}

\section{Transmission Electron Microscopy (TEM) of (nSe) sample}

Under TEM, nanoselenium (nSe) sample appeared as regular spheres and distributed homogeneously, the image revealed diameter of $54 \mathrm{~nm}$ average at magnification of 200 kx, as shown in Figure (1).

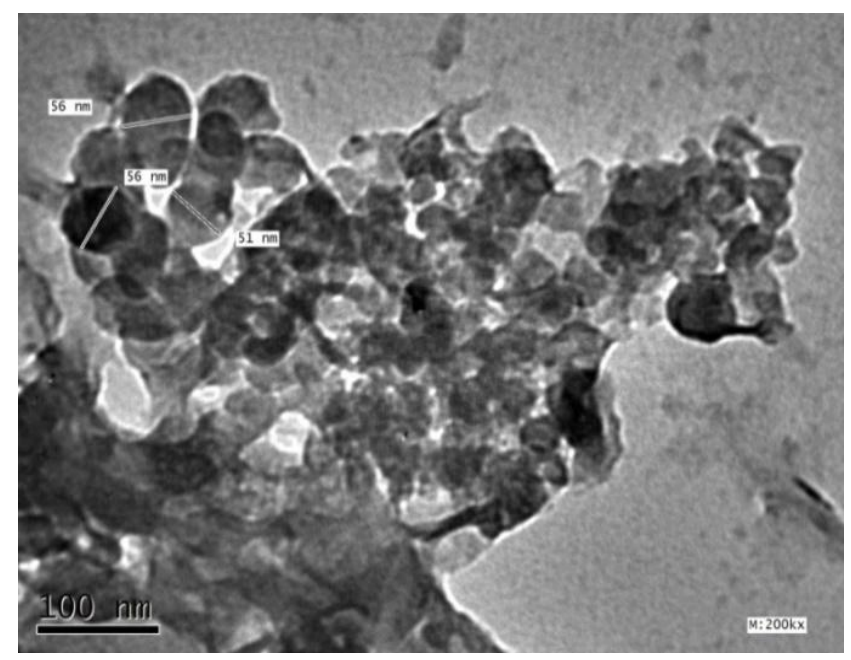

Fig 1: TEM image of nanoselenium.

\section{Liver function parameters}

Data of this work revealed that the intoxication in DENinduced animals, lead to highly significant increase $(p<$ 0.001) in plasma AST and ALT activities as well as albumin concentration each compared to the normal control. 
However, the data showed highly significant decrease ( $p$ $<0.001)$ in total protein concentration compared with corresponding normal control group.

Treatment of the animals in group 5 and 6 by the drugs, HEx and nSe, respectively, improved the case by highly significant $(p<0.001)$ decrease in AST and ALT activities as well as the albumin concentration relative to group 4 (DEN).

On the other hand the treatment by the drugs revealed significant $(p<0.001)$ elevation of total protein concentration compared with group 4 (DEN), the results are depicted in Table (1).

Kidney Function Parameters

It is known that Plasma urea and creatinine rise in damaged kidney. In the present study, data of DENinduced groups revealed highly significant increase $(p<$ 0.001 ) in urea plasma and creatinine concentration compared with corresponding normal control group.

Sort of relief and improvement was noticed in the tumordrug treated groups (groups 5 and 6). These groups exhibited significant decrease in urea and creatinine levels relative to DEN-treated group 4 (Table 2).

Table 1: Plasma AST and ALT activities, and albumin and total protein levels of DEN-induced hepatocellular carcinoma and treated with $H$. sabdariffa extract and nanoselenium in rats.

\begin{tabular}{|c|c|c|c|c|c|}
\hline \multicolumn{2}{|c|}{ Groups } & $\begin{array}{l}\text { AST }(\mathbf{U} / \mathbf{L}) \\
\text { Mean } \pm \text { SD }\end{array}$ & $\begin{array}{l}\text { ALT (U/L) } \\
\text { Mean } \pm \text { SD }\end{array}$ & $\begin{array}{c}\text { Albumin }(\mathrm{g} / \mathrm{dL}) \\
\text { Mean } \pm \text { SD }\end{array}$ & $\begin{array}{c}\text { Total proteins }(\mathrm{g} / \mathrm{dL}) \\
\text { Mean } \pm \text { SD }\end{array}$ \\
\hline \multirow{3}{*}{ 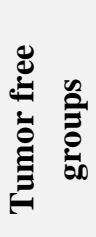 } & 1- Control & $18.25 \pm 1.80^{b}$ & $13.84 \pm 3.30^{b}$ & $2.18 \pm 0.08^{b}$ & $8.48 \pm 0.24^{b}$ \\
\hline & 2- HEx & $18.87 \pm 3.11^{b}$ & $15.45 \pm 4.33^{b}$ & $2.51 \pm 0.13^{b}$ & $8.42 \pm 0.32^{b}$ \\
\hline & 3- nSe & $17.95 \pm 4.48^{b}$ & $14.72 \pm 3.56^{b}$ & $2.57 \pm 0.14^{b}$ & $8.58 \pm 0.18^{b}$ \\
\hline \multirow{3}{*}{ 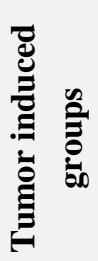 } & 4- DEN & $69.90 \pm 7.19^{a}$ & $86.14 \pm 5.53^{a}$ & $5.12 \pm 0.17^{\mathrm{a}}$ & $3.19 \pm 0.19^{a}$ \\
\hline & 5- DEN + HEx & $32.17 \pm 3.64^{\mathrm{ab}}$ & $22.89 \pm 8.45^{\mathrm{ab}}$ & $3.35 \pm 0.18^{\mathrm{ab}}$ & $5.57 \pm 0.26^{\mathrm{ab}}$ \\
\hline & 6- $\mathrm{DEN}+\mathrm{nSe}$ & $46.79 \pm 7.20^{\mathrm{ab}}$ & $20.34 \pm 5.73^{b}$ & $3.31 \pm 0.36^{\mathrm{ab}}$ & $5.42 \pm 0.32^{\mathrm{ab}}$ \\
\hline
\end{tabular}

$\mathrm{N}=6$. Results were expressed as Mean $\pm \mathrm{SD}$. $\mathrm{P}<0.05$; a, significant vs. control group; b, significant vs. DEN group. HEx, $H$. sabdariffa extract; nSe, nanoselenium; DEN, diethylnitrosamine.

Table 2: Plasma urea and creatinine levels of DEN-induced hepatocellular carcinoma and treated with $H$. sabdariffa extract and nanoselenium in rats.

\begin{tabular}{|c|c|c|c|}
\hline \multicolumn{2}{|c|}{ Groups $\quad$ Parameters } & $\begin{array}{c}\text { Urea }(\mathrm{mg} / \mathrm{dL}) \\
\text { Mean } \pm \mathrm{SD}\end{array}$ & $\begin{array}{c}\text { Creatinine }^{*}(\mathrm{mg} / \mathrm{dL}) \\
\text { Mean } \pm \mathrm{SD}\end{array}$ \\
\hline \multirow{3}{*}{ 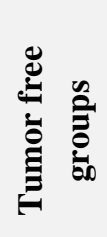 } & 1- Control & $76.04 \pm 6.09^{b}$ & $0.55 \pm 0.05^{b}$ \\
\hline & 2- HEx & $80.21 \pm 8.34^{b}$ & $0.61 \pm 0.08^{b}$ \\
\hline & 3- nSe & $89.8 \pm 10.36^{a b}$ & $0.71 \pm 0.10^{b}$ \\
\hline \multirow{3}{*}{ 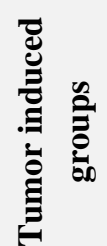 } & 4- DEN & $153.79 \pm 4.86^{\mathrm{a}}$ & $1.04 \pm 0.82^{a}$ \\
\hline & 5- DEN + HEx & $104.38 \pm 7.53^{a b}$ & $0.82 \pm 0.14^{\mathrm{ab}}$ \\
\hline & 6- DEN + nSe & $112.92 \pm 12.29^{a b}$ & $0.81 \pm 0.12^{a b}$ \\
\hline
\end{tabular}

$\mathrm{N}=6 . * \mathrm{~N}=4$, Results were expressed as Mean $\pm \mathrm{SD}$. $\mathrm{P}<0.05$; a, significant vs. control group; , significant vs. DEN group. HEx, H. sabdariffa extract; nSe, nanoselenium; DEN, diethylnitrosamine. 
The blood antioxidant and oxidative stress parameters

The effect of DEN treatment as induced hepatic toxicity appears throughout highly significant decrease $(p<$ 0.001 ) in the level of hepatic antioxidant GSH as well as SOD and CAT activities in DEN-induced groups (groups 4 through 6) each compared with the corresponding normal control level.

However, HEx and nSe administration to the tumor groups (5 and 6, respectively) improved this effect.

On the other hand HEx treated without DEN-induction, group 2 revealed highly significant increase $(p<0.001)$ in GSH content relative to normal control.

In case of SOD and CAT groups 2 and 3 revealed no significant change in their activities towards normal control (Table 3).

The oxidative stress parameter MDA represented highly increase in blood lipid peroxidation, measured as the plasma level of the end product malondialdehyde. By treatment of the tumor groups (5 and 6 with HEx and nSe, respectively), both groups showed highly significant decrease $(p<0.001)$ in MDA level compared with group 4 (DEN) (Table 3).

\section{Tumor marker parameters}

Caspase-3 plays an important role during apoptotic cell death. Intoxication of the animals by DEN leads to highly significant decrease $(p<0.001)$ in caspase-3 activity relative to the normal control group. Treatment of group 5 by HEx and group 6 by nSe showed significant increase $(p<0.001$ and $p<0.05$, respectively) in caspase-3 activity in comparison with group 4, DEN (Table 4).

In contrast DEN induction leads to significant elevation $(p<0.01$ and 0.001$)$ in TNF- $\alpha$ activity and AFP level, respectively, relative to the normal control.
HEx and nSe administration in drug-tumor groups (5 and 6 , respectively) improved both marker levels by significant decrease $(p<0.05)$ in TNF- $\alpha$ activity as well as decrease at $p<0.01$ for HEx and at $p<0.001$ for nSe in AFP level compared to group 4 (Table 4).

\section{Histopathological Examination results}

Histopathological examination was performed in the liver of all groups of the animals investigated in the present study. Liver sections of normal control (Figure 2a), HEx (Figure 2b) supplementation groups revealed no histopathological alterations, hepatic lobules was observed. Liver section from nSe treated animals exhibited apparent normal hepatic lobules (Figure 2c). On the other hand examination of liver tumor induced animals revealed morphological changes compared with the normal control. Histological structure of the liver section showed dysplastic hepatocytic nodules surrounded by fibrosis connective tissues (Figure 2d). Examination of liver sections from group 5 (DEN + HEx) exhibited fatty acid degeneration of hepatocytes (Figute 2e). Examination of liver section from group 6, $(\mathrm{DEN}+\mathrm{nSe})$ revealed no histopathological alteration (Figure 2f).

\section{Discussion}

Hepatocellular carcinoma (HCC) represents the fifth most common malignancy and the main cause of mortality in patients with chronic liver diseases. HCC is a tumor that is characterized by high local invasiveness and high metastatic potential ${ }^{[4]}$. Selective and efficient targeting of cancer cells is the foremost goal in the development of anti-cancer therapeutics ${ }^{[46]}$.

In recent decades, attention has been focused on the anticancer properties of several components of diet and food for application in cancer chemoprevention. The phenolic compounds such as flavonoids and anthocyanins are type

Table 3: Blood levels of malondialdehyde and GSH as well as SOD and catalase activities of DEN-induced Hepatocellular carcinoma and treated with $H$. sabdariffa extract and nanoselenium, in rats.

\begin{tabular}{|c|c|c|c|c|c|}
\hline \multicolumn{2}{|c|}{ Groups } & $\begin{array}{c}\operatorname{MDA}(\mu \mathrm{M} / \mathrm{L}) \\
\operatorname{Mean} \pm \mathrm{SD}\end{array}$ & $\begin{array}{c}\text { GSH }(\mathrm{mg} / \mathrm{dL}) \\
\text { Mean } \pm \text { SD }\end{array}$ & $\begin{array}{c}\text { SOD }(\mu \mathrm{g} / \mathrm{ml}) \\
\text { Mean } \pm \text { SD }\end{array}$ & $\begin{array}{c}\text { CAT }(\mu \mathrm{mol} / \mathrm{ml}) \\
\text { Mean } \pm \text { SD }\end{array}$ \\
\hline \multirow{3}{*}{ 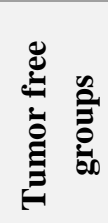 } & 1-Control & $33.05 \pm 1.56^{b}$ & $71.33 \pm 4.44^{b}$ & $4.16 \pm 0.16^{b}$ & $23.07 \pm 1.67^{b}$ \\
\hline & 2- HEx & $19.78 \pm 3.09^{a b}$ & $83.02 \pm 2.63^{a b}$ & $3.99 \pm 0.19^{b}$ & $22.80 \pm 4.27^{b}$ \\
\hline & 3- nSe & $23.22 \pm 2.42^{\mathrm{ab}}$ & $75.37 \pm 2.09^{b}$ & $3.83 \pm 0.21^{b}$ & $26.12 \pm 3.26^{b}$ \\
\hline \multirow{3}{*}{ 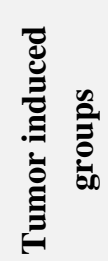 } & 4- DEN & $75.72 \pm 6.44^{\mathrm{a}}$ & $20.94 \pm 4.64^{\mathrm{a}}$ & $1.48 \pm 0.27^{\mathrm{a}}$ & $10.86 \pm 3.0^{\mathrm{a}}$ \\
\hline & 5- DEN + HEx & $50.44 \pm 1.34^{\mathrm{ab}}$ & $44.94 \pm 5.44^{\mathrm{ab}}$ & $2.81 \pm 0.43^{\mathrm{ab}}$ & $16.69 \pm 1.88^{a b}$ \\
\hline & 6- $\mathrm{DEN}+\mathrm{nSe}$ & $55.77 \pm 2.53^{\mathrm{ab}}$ & $41.87 \pm 4.60^{a b}$ & $2.98 \pm 0.20^{\mathrm{ab}}$ & $15.69 \pm 1.97^{\mathrm{ab}}$ \\
\hline
\end{tabular}

$\mathrm{N}=6$. Results were expressed as Mean $\pm \mathrm{SD}$. P <0.05; a, significant vs. control group; b, significant vs. DEN group. HEx, $H$. sabdariffa extract; nSe, nanoselenium; DEN, diethylnitrosamine. 
Table 4: Liver Caspase-3, and plasma TNF- $\alpha$ and AFP levels of DEN-induced hepatocellular carcinoma treated with H. sabdariffa extract and nanoselenium in rats.

\begin{tabular}{|c|c|c|c|c|}
\hline \multicolumn{2}{|c|}{$\begin{array}{ll}\text { Groups } & \text { Parameters }\end{array}$} & $\begin{array}{c}\text { Caspase-3 }(\mathrm{U} / \mathrm{mL}) \\
\text { Mean } \pm \mathrm{SD}\end{array}$ & $\begin{array}{c}\text { TNF- } \alpha(\mathrm{U} / \mathrm{L}) \\
\text { Mean } \pm \text { SD }\end{array}$ & $\begin{array}{l}\operatorname{AFP}(n g / m L) \\
\text { Mean } \pm \text { SD }\end{array}$ \\
\hline \multirow{3}{*}{ 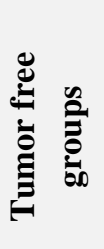 } & 1- Control & $256.90 \pm 20.71^{b}$ & $6.73 \pm 0.79^{b}$ & $20.13 \pm 2.15^{b}$ \\
\hline & 2- HEx & $341.83 \pm 5.57^{a b}$ & $6.97 \pm 0.56^{b}$ & \\
\hline & 3- nSe & $309.40 \pm 4.90^{\mathrm{ab}}$ & $11.74 \pm 2.27$ & \\
\hline \multirow{3}{*}{ 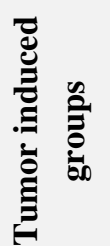 } & 4- DEN & $171.82 \pm 2.63^{a}$ & $16.64 \pm 5.54^{\mathrm{a}}$ & $150.13 \pm 18.05^{a}$ \\
\hline & 5- DEN + HEx & $203.53 \pm 10.22^{\mathrm{ab}}$ & $10.07 \pm 5.74^{b}$ & $110.07 \pm 26.44^{\mathrm{ab}}$ \\
\hline & 6- $\mathrm{DEN}+\mathrm{nSe}$ & $195.00 \pm 3.13^{\mathrm{ab}}$ & $8.77 \pm 3.64^{b}$ & $60.10 \pm 8.85^{\mathrm{ab}}$ \\
\hline
\end{tabular}

$\mathrm{N}=3$, Results were expressed as Mean \pm SD. $\mathrm{P}<0.05$; a, significant vs. control group; b, significant vs. DEN group. HEx, $H$. sabdariffa extract; nSe, nanoselenium; DEN, diethylnitrosamine.
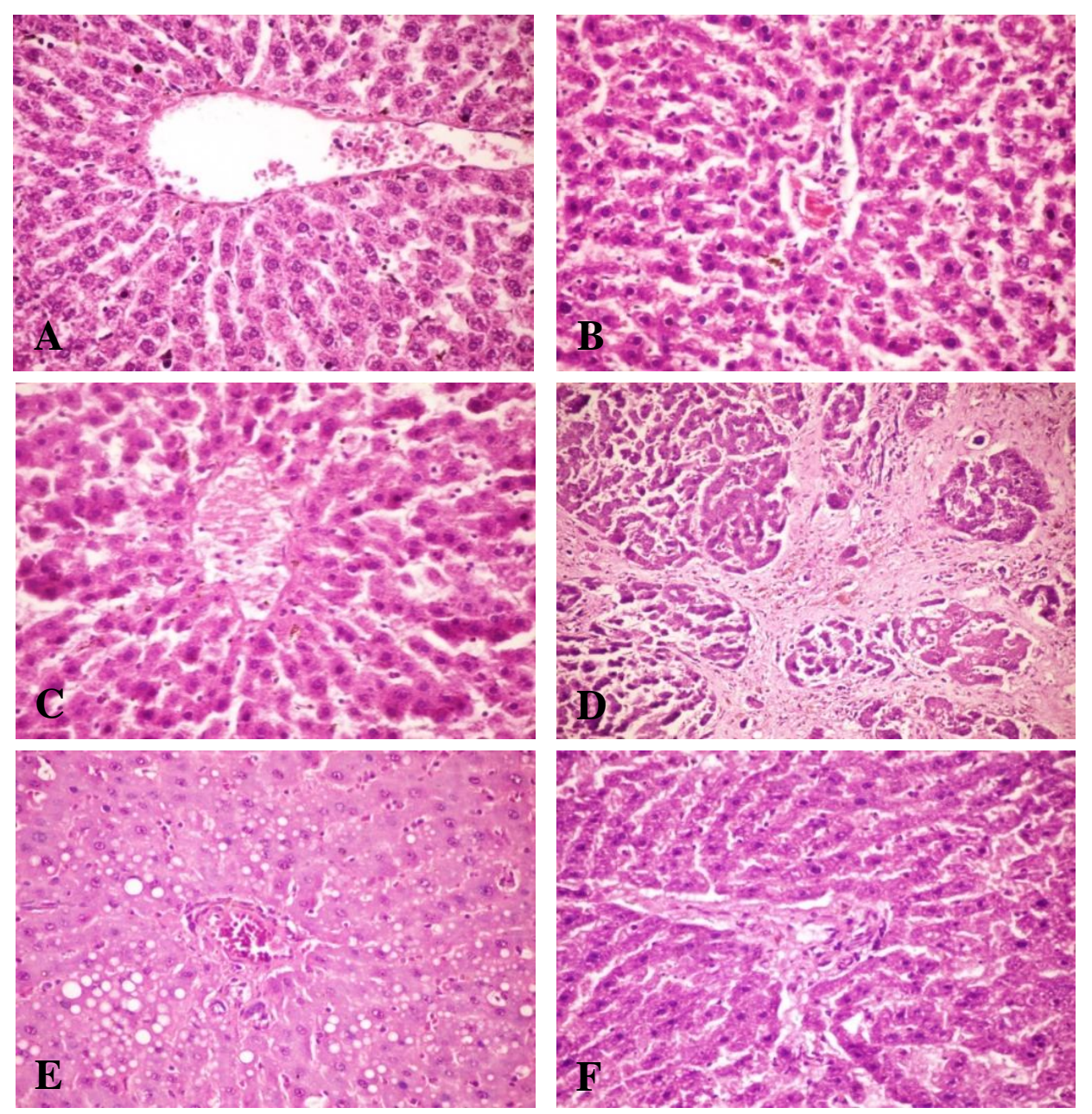

Figure 2: Liver sections of: a) normal control rat showing normal histological structure of hepatic lobule. b) rats administrated Hibiscus Extract (HEx) showing apparent normal hepatic lobule. c) rats supplemented nanoselenium (nSe) showing apparent normal hepatic lobule. d) DEN-injected rat, showing dysplastic nodules surrounded by fibrotic connective tissue. e) rats supplemented with DEN + HEx showing fatty degeneration of hepatocytes. f) rats supplemented with DEN + nSe showing no histopathological changes. (H and E, X 400). 
of major benzoic acid derivatives from vegetables and fruits that have strong anti-oxidant property ${ }^{[47-49]}$. Protocatechuic acid (a simple phenolic compound) detected in $H$. sabdariffa could be used to fight liver disorders.

In the present study water extract of $H$. sabdariffa $\mathrm{L}$. calyx and nanoselenium were studied to assess their efficacy as chemo-preventive agents against hepatocellular carcinoma in rats.

Diethylnitrosamine (DEN) a well-known hepatocarcinogen has been reported to generate free radicals to exert its carcinogenic effects. It induces the production of reactive oxygen species (ROS) which trigger the genotoxic effect of $N$-nitroso carcinogens that induce DNA adducts, DNA strand breaks and unscheduled DNA synthesis ${ }^{[50,51]}$. DEN enhances the formation of ethyl-DNA adducts which can interrupt base-pairing and inhibit tumor suppressor gene p53 ${ }^{[52]}$. Because of the presence of this carcinogen in the environment around man, DEN was chose to induce neoplasm in this study.

Selenium compounds also exhibit antioxidant and radioprotecting activity and are free radical scavengers [53]. A few studies utilized elemental selenium $\left(\mathrm{Se}^{0}\right)$ due to the notion that colloidal selenium has very low bioavailability and biological activity. But it has been reported that particles of selenium stabilized to nanometer size exhibit high biochemical activity and have improved bioavailability, it is stated that the oxidizing power of nanoselenium depends on the size of the nanoparticle ${ }^{[54,55]}$. Accordingly, powder selenium was prepared in nano-form by ball milling, where different nano-forms were obtained ranges between 50$56 \mathrm{~nm}$ as shown in TEM photography (Figure 1).

Due to liver damage in DEN-induced groups, liver function parameters AST and ALT as well as albumin level rise in comparison with control, whereas total protein level was decreased. Increase in liver function parameters AST and ALT (Table 1) is a consequence of liver injury which leads to release of its cytosolic proteins into blood circulation. While AST is found in every tissue of the body, including red blood cells, and is particularly high in the cardiac muscle, ALT is present in moderately high concentration in liver and low in cardiac, skeletal muscle and other tissues therefore high ratio of ALT/AST is more useful in the diagnosis and monitoring of patients with hepatocellular disease, this work in consistent with these facts as stated by Nyblom,

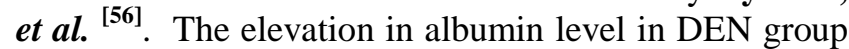
compared with normal control (Table 1) implies that the increase in albumin may be as a result of neoplasm as liver damage, which was reduced towards normal control value by treatment (HEx and nSe). This result agrees with that of Ekanem and Yusuf ${ }^{[57]}$.

Kidney function parameters (Plasma urea and creatinine) were evoked due to some damage in liver and kidney within the tumor induced group relative to the normal control (Table 2) and this finding is in harmony with that of Al-Okbi et al. ${ }^{[58]}$.
The use of medicinal plant products to manage or arrest the carcinogenic process provides an alternative to the use of conventional allopathic medicine for treatment of the disease it seems to be emerging approaches that include not only cytotoxic approaches but also molecular management of cancer physiopathology.

In the present work, the differences in the oxidative stress-related parameter between healthy rats and rats with DEN-induced tumors have been tested as level of malondialdehyde (MDA). Increased free radicals via $\mathrm{H}_{2} \mathrm{O}_{2}$ generation and imbalances in oxidant/antioxidant balance is oxidative stress, which leads to oxidative damage, resulting in increased MDA levels (end product of lipid peroxidation) significantly $(p<0.001)$ in tumor groups relative to normal control. Treatment by HEx and by nSe markedly decrease $(p<0.001)$ that level giving an indication of tissue relief (Table 3) this findings in contestant and supports Olusola, et al. ${ }^{[59]}$ findings. Endogenous antioxidant enzymatic systems can be damaged during food processing (particle size reduction and heating), by certain ingredients (salts and organic acids), and by storage conditions (presence of oxygen) such that they are ineffective ${ }^{[60,61]} . \mathrm{NaCl}$, in particular, reduces the activity of the antioxidant enzymes catalase, GPx, and SOD that reduces their capacity to perform antioxidative functions ${ }^{[61,62]}$.

Natural antioxidant defense mechanism prevents formation of excessive free radicals. The antioxidants may act as free radical scavengers, reducing agents, chelating agents for transition metals, quenchers of singlet oxygen molecules and activators of anti-oxidative enzymatic defense system to suppress free radical damage in biological systems ${ }^{[49]}$. Glutathione is one of the most abundant tripeptide, non-enzymatic biological antioxidant present in the liver. It removes free radical species such as hydrogen peroxide, superoxide radicals and maintains membrane protein thiols. Decreased level of GSH is associated with an enhanced lipid peroxidation in DEN-induced rats. Administration of $H$. sabdariffa extract containing anthocyanins and nanoselenium significantly $(p<0.001)$ increased the level of GSH hence GPx. Plant pigments anthocyanins can chelate metals and donate hydrogen to oxygen radicals so slowing oxidation ${ }^{[63]}$. The free radical-scavenging potential of natural polyphenolic compounds appears to depend on the pattern (both number and location) of free $-\mathrm{OH}$ groups on the flavonoid skeleton and this give advantage to anthocyanins and flavonoids to be strong natural antioxidants ${ }^{[62]}$ as obtained by our study.

The protective effect of $H$. sabdariffa on DEN-induced hepatotoxicity in rats appears to be related to inhibition of lipid peroxidation and enhancement of antioxidant enzyme levels in addition to free radicals scavenging action (Table 3). Preliminary phytochemical studies reveal the presence of anthocyanins in plants extracts. Comparison of antioxidant properties of anthocyanins with widely known antioxidants showed that these compounds had higher antioxidant activity than vitamin E ( $\alpha$-tocopherol), ascorbic acid and $\beta$-carotene ${ }^{[64]}$. 
In our study, DEN-induction reduce antioxidant enzymatic system which comprise SOD and catalase and non-enzyme antioxidant GSH (which affected by GPx) the finding is depicted in Table (3). The results obviously indicate that the chemopreventive of the drugs under investigation (HEx and nSe) elevate the level of the defense system of the animals, leading to neoplastic resistant as shown in histopathological figures. This result is in harmony with ${ }^{[65,66]}$.

Caspase- 3 is one of the important members of Caspases that induce apoptosis. Caspase- 3 activation plays a key role in initiation of cellular events during the early apoptotic process. In the present study, caspase- 3 is reduced significantly in DEN groups relative to the normal control, this reduction may lead to free radical generation in the tissue forming $\mathrm{OH}$ radical and $\mathrm{H}_{2} \mathrm{O}_{2}$ which is associated with mutation, then initiation of hepatocarcinoma and progression of hepatic cancer in the animals under study.

Significant increase $(p<0.05)$ has been recorded in the level of caspase-3 in DEN-induced group treated by HEx (also that treated by nSe) emphasizing the role of anthocyanins of $H$. sabdariffa in apoptosis activation of infected cell. According to Afaq, et al. ${ }^{[67]}$ the proapoptotic activity of anthocyanins was reported in different cell lines and involves multiple pathways, such as caspase activation, p53 and bax protein increase, and ERK $1 / 2$ and Akt kinase activation.

On the other hand significant increase in tumor inflammatory marker, TNF- $\alpha$ level in the plasma (Table 4) was recorded in DEN group. $T N F-\alpha$ is the main cytokine that mediates acute inflammation and stimulates the cells to produce selectins and the leukocytes to express integrins, leading to activation of the coagulation pathway. This event increases the production of chemokines in endothelial cells and macrophages, to activate neutrophils and their killer activity, etc... ${ }^{[68]}$. Dis-regulation of TNF production has been implicated in a variety of human diseases, including cancer [69]. Treatment by HEx and nSe significantly decrease $(p<0.05)$ the level of TNF- $\alpha$ (Table 4).

Increased AFP levels may indicate the presence of cancer, most commonly liver cancer, ovary cancer, or germ cell tumor of the testes. However, not every liver, ovarian, or testicular cancer will produce significant quantities of AFP. Other diseases such as cirrhosis and hepatitis can also cause increased levels [70]

When AFP is used as a monitoring tool, decreasing levels indicate a response to treatment. If concentrations after cancer treatment do not significantly decrease to normal or near normal levels, then some of the tumor tissue may still be present. If concentrations begin to increase, then it is likely that the cancer is recurring. However, since AFP can be increased in hepatitis or cirrhosis, AFP levels can sometimes be misleading. If AFP levels are not elevated prior to treatment, then the test will not generally be useful to monitor the effective- ness of treatment or to monitor for recurrence ${ }^{[71]}$.

Our results showed high significant elevation level of AFP in DEN group relative to normal control group. However, treatment by HEx and nSe significantly decreased ( $p<0.01$ and $p<0.001$, respectively) the level of AFP. The histopathological finding of this study (Figure 2) is in harmony and emphasizes the rest of the study.

Conclusion: The results of the present study give scientific evidences that both $H$. sabdariffa extract $(250$ $\mathrm{mg} / \mathrm{Kg}$ b.w, thrice/week) and nanoselenium (2 $\mathrm{mg} / \mathrm{Kg}$ b.w, twice/ week) have chemo-protection efficiency against HCC induced by DEN in rats, and may play an important role in health promotion in terms of anticancer effects and are worthy of further investigation leading to their clinical development.

\section{References}

1) Yao D. F., Dong, Z. Z. and Yao, M. (2007). Specific molecular markers in hepatocellular carcinoma. Hepatobiliary Pancreat Dis Int., 6(3): 241-247.

2) Strivatanakul, P., Sriplung, H. and Deerasamee, S. (2004). Epidemiology of Liver Cancer: An Overview. Asian Pac. J. Cancer Prev., 5:118-125.

3) Salim, E., Moore, M., Al-Lawati, J., Al-Sayyad, J., Bazawir, A., Bener, A., Corbex, M., El-Saghir, N., Habib, O. S., Maziak, W., Mokhtar, H. C., Seif-Eldrin, I. A. and Sobue T. (2009). Cancer epidemiology and control in the Arab world-past, present and future. Asian Pac. J. Cancer Prev., 10: 316.

4) Anwar, W. A., Khaled, H. M., Amra, H. A., ElNezami, H. and Loffredo, Ch. (2008). Changing pattern of hepatocellular carcinoma (HCC) and its risk factors in Egypt: Possibilities for prevention. Mutation Research, 659: 176-84.

5) Abdel-Hamid, M., El-Daly, M., Molnegren, V., El-Faramawy, S., Abdel-Latif, S., Esmat, G., Strickland, G. T., Loffredo, C., Albert, J. and Widell, A. (2007). Genetic Diversity In Hepatitis C Virus In Egypt And Possible Association With Hepatocellular Carcinoma. J. Gen. Virol. 88(5): 1526-1531.

6) Hifnawy, M. S., Mangoud, A. M., Eissa, M. H., Nor Edin, E., Mostafa, Y., Abouel-Magd, Y., Sabee, E. I., Amin, I., Ismail, A., Morsy, T. A., Mahrous, S., Afefy, A. F., el-Shorbagy, E., ElSadawy, M., Ragab, H., Hassan, M. I., El-Hady, G. and Saber, M. (2004). The role of aflatoxincontaminated food materials and $\mathrm{HCV}$ in developing hepatocellular carcinoma in Al-Sharkia Governorate, Egypt. J. Egypt Soc. Parasitol., 34: 479-488.

7) Abdel-Wahab, M., El-Ghawalby, N., Mostafa, M., Sultan, A., El-Sadany, M., Fathy, O., Salah, T. and Ezzat, F. (2007). Epidemiology of hepatocellular carcinoma in Lower Egypt, Mansoura Gastroenterology Center. Hepatogastroenterology, 54(73):157-162. 
8) El-Zayadi, A., Badran, H. M., Barakat, E. M., Attia, M. E., Shawky, S., Mohamed, M. K., Selim, O. and Saeid, A. (2005). Hepatocellular carcinoma in Egypt: A single center study over a decade. World J. Gastroenterol, 11(33): 5193-5198.

9) Abdel-Atti, E. (2015). HCC Burden in Egypt. Gastoentero. Hepato. Open Access, 2(3):1-2.

10) Cheung-Ong, K., Giaever, G., and Nislow, C. (2013). DNA-damaging agents in cancer chemotherapy: serendipity and chemical biology. Chem. Biol., 20(5): 648-659.

11) Mustafa, T., Mogga, J. S., Mfinanga, S. G. M., Morkve O. and Sviland L. (2006). Immunohistochemical analysis of cytokines and apoptosis in tuberculous lymphadenitis. Immunol. 117: 454-462.

12) Bharti, A. C. and Aggarwal, B. B. (2002). Nuclear factor- $\kappa \mathrm{B}$ and cancer: its role in prevention and therapy. Biochem. Pharmacol. 64: 883-888.

13) Hassan, M. M., Li, D., El-Deeb, A. S., Wolff, R. A., Bondy, M. L., Davila, M. and Abbruzzese, J. L. (2008). Association between hepatitis B virus and pancreatic cancer. J. Clin. Oncol., 26(28): 45574562.

14) Iddamaldeniya, S. S., Wickramasinghe, N., Thabrew, I., Ratnatunge, N. and Thammitiyagodage, M.G. (2003). Protection against diethylnitrosamine-induced hepatocarcinogenesis by an indigenous medicine comprised of Nigella sativa, Hemidesmus indicus and Smilax glabra: a preliminary study. J. Carcinogenesis, 2: 1-6.

15) Ali, B. H. (2004). The effect of Nigella sativa oil on gentamicin nephrotoxicity in rats. The Am. J. Chinese Med., 32: 49-55.

16) Mohamed, B. B., Suliman, A. A. and Dahab, A. A. (2012). Roselle (Hibiscus sabdariffa L.) in Sudan, cultivation and their uses. Bul. Env. Pharm. Life Sci., 1(6): 48 - 54.

17) Kanadaswami, C., Lee, L., Lee, P. H., Hwang, J., Ke, F. and Huang, Y. (2005). The antitumor activities of flavonoids. In Vivo. 19(5): 895-909.

18) Onyenekwe, P. C., Ajani, E. O., Ameh, D. A. and Gamaniel, K. S. (1990). Antihypertensive effect of roselle (Hibiscus sabdariffa) calyx infusion in spontaneously hypertensive rats and comparison of its toxicity with that in Wistar rats. Cell Biochem. Funct. 17(3): 199- 206.

19) Wang, H., Zhang, J. and Yu, H. (2007). Elemental selenium at nano size possesses lower toxicity without compromising the fundamental effect on selenoenzymes: comparison with selenomethionine in mice. Free Radic. Biol. Med., 42(10):1524-1533.

20) Cuparigova, F. and Stafilov, T. (2011). Determination of Selenium in Human Blood Serum by Electrothermal Atomic Absorption Spectrometry. Chem. Sci. J., 46: 1-8.
21) Behne, D., and Kyriakopoulos, A. (2001). Mammalian selenium containing proteins. Annu. Rev. Nutr., 21:453-473.

22) Upham, B. L., and Trosko, J. E. (2009). Oxidativedependent integration of signal transduction with intercellular gap junctional communication in the control of gene expression. Antioxid. Redox. Signal, 11: 1-11.

23) Barrett, J. R. (2000). Mycotoxins of molds and maladies. Envir. Health Perspectives, 108(1): A20 A23.

24) Combs, G. F. and Gray, W. P. (1998). Chemopreventive agents: selenium. Pharmacol. and Therapeu. 79: 179-192.

25) Spallholz, J. E. (1994). On the nature of selenium toxicity and carcinostatic activity. Free Radical Biol. Med., 17:45-64.

26) Reid, M. E., Stratton, M. S., Lillico, A. J., Fakih, M., Natarajan, R., Clark, L. C., and Marshall, J. R. (2004). A report of high-dose selenium supplementation: Response and toxicities. J. Trace Elem. Med. Biol., 18: 69-74.

27) Zhang, S. Boyd, J. Delaney, K. and Murphy, T. H. (2005). Rapid reversible changes in dendritic spine structure in vivo gated by the degree of ischemia. $\mathrm{J}$. Neuroscience, 25(22): 5333-5338.

28) Jia, X., Li, N., and Chen, J. (2005). A subchronic toxicity study of elemental nano-Se in Sprague Dawley rats. Life Sci., 76(17):1989-2003.

29) Builders, P. F., Chukuemeka, R. E., Florence, D.T., and Builders, M. I. (2010). Assessment of intrinsic properties of the freeze-dried and formulated extract of Hibiscus sabdariffa Linn. (Malvaceae). Afric, J. Pharmacy and Pharmaco., 4(6): 304-313.

30) Henriquez, R., Gomez, H., Riveros, G., Guillemoles, J. F., Froment, M. and Lincot, D., (2004). Electrochemical deposition of $\mathrm{ZnSe}$ from dimethyl sulfoxide solution and characterization of epitaxial growth J. Physical Chem B, 108:1319113199.

31) Klaunig, J. E., Pereira, M. A., Ruch, R. J. and Weghorst, C. M. (1988). Dose-response relationship of diethylnitrosamine-initiated tumors in neonatal balb/c mice: effect of phenobarbital promotion. Toxicol. Pathol., 16(3): 381-385.

32) Dragan, Y. P., Xu, Y. H. and Pitot, H. C. (1993). The effect of the dose of diethylnitrosamine on the initiation of altered hepatic foci in neonatal female rats Carcinogenesis. Mar, 14(3): 385-391.

33) Reitman, S. and Frankel, S. (1957). The colorimetric method for determination of serum glutamic oxaloacetic transaminase and serum glutamic pyruvic transaminase. Am. J. Clin. Pathol., 28: $56-63$.

34) Gornal, A. G., Bardwil, G. S. and David, M. M. (1949). Determination of serum proteins by mean of Biuret reactions. Biochemistry, 177: 751-766. 
35) Doumas, B. T., Whatson, W. A. and Biggs, H. G. (1971). Albumin standard and the measurement of serum albumin with bromcresol green. Clin. Chim, Acta. 31: 87-96.

36) Bartels, H., Bohmer, M. and Heierli, C. (1972). Serum creatinine determination without protein precipitation. Clinica. Chemica. Acta 37: 193-197.

37) Fawcett, A. and Soctt, J. (1960). A Rapid and Precise Method for the determination of Urea. J. Clin. Path., 13: 156-159.

38) Yoshioka, T., Kawada, K., Shimada, T. and Movi, M. (1979). Lipid peroxidation in maternal and cord blood and protective mechanism against activated oxygen toxicity in the blood. Am. J. Obstet. Gynec., 135: 372-376.

39) Beutler, E., Duron, O. and Kelly, B. M. (1963). Improved method for the determination of blood glutathione. J. Lab Clin. Med., 61: 882-888.

40) Minami, M. and Yoshikawa, H. (1979). A simplified assay method of superoxide dismutase activity for clinical use. Clin. Chim. Acta. 92: 337342.

41) Sinha, A. K. (1972). Colorimetric assay of catalase. Anal. Biochem., 47: 389.

42) Tonner, E., Barber, M. C., Allan, G. J., Beattie, J., Webster, J. and Whitelaw, C. B. (2002). Insulin-like growth factor binding protein-5 (IGFBP-5) induces premature cell death in the mammary glands of transgenic mice. Development, 129: 4547-4557.

43) Hirai, H. (1982). Alpha fetoprotein. In: Chu TM. (ed.) Biochemical Markers for Cancer. Marcel Dekker, New York, pp 23-59.

44) Banchroft, J. D., Stevens, A. and Turner, D. R. (1996). Theory and practice of histological techniques. Fourth Ed. Churchil Livingstone, New york, London, San Francisco, Tokyo.

45) Hassan, M., Selimovic, D., Ghozlan, H. and AbdelKader, O. (2009). Hepatitis C virus protein triggers hepatic angiogenesis by a mechanism including multiple pathways. Hepatology, 49(5): 1469-1482.

46) Pabla, N. and Dong, Z. (2012). Curtailing side effects in chemotherapy: a tale of $\mathrm{PKC} \delta$ in cisplatin treatment.Oncotarget., 3(1):107-111.

47) Lin, J. K., Liang, Y. C. and Lin-Shiau, S. Y. (1999). Cancer chemoprevention by tea polyphenols through mitotic signal transduction blockade. Biochem. Pharmacol., 58: 911-915.

48) Ologundudu, A., Ologundudu, A. O., Oluba, O. M., Omotuyi, I. O., and Obi, F. O. (2010). Effect of Hibiscus sabdariffa anthocyanins on 2, 4dinitrophenylhydrazine-induced tissue damage in rabbits. J. Toxicol. Envir. Health Sci. 2(1): 1-6.

49) Abdel-Ghaffer, F. R. (2013). Attenuation of $\mathrm{CCl}_{4}$ induced hepatic antioxidants disorder and oxidative stress by Hibiscus rosasinensis extract in albino rats. Int. J. Med. Plant Altern. Med. 1(1): 1-12.

50) Sekihashi, K., Yamamoto, A., Matsumura, Y., Ueno, S., Watanabe-Akanuma, M., Kassie, F., Knasmüller, S., Tsuda, S. and Sasaki, Y. F. (2002). Comparative investigation of multiple organs of mice and rats in the comet assay. Mutat. Res., 517: 53-75.

51) Galhena, P., Thabrew, I., Tammitiagodagi, M. G., and Rachel, V. A. H. (2009). Antihepatocarcinogenic Ayurvedic herbal remedy reduces the extent of diethylnitrosamine-induced oxidative stress in rats. Pharmacog. Magaz., 5(17): 19-27.

52) Beer, D. G., Schwarz, M., Sawada, N. and Pitot, H. C. (1986). Expression of H-ras and cmycprotooncogenes in isolated gamma-glutamyl transpeptidase-positive rat hepatocytes and in hepatocellular carcinomas induced by diethylnitrosamine. Cancer Res., 46: 2435-2441.

53) Mishra, B., Priyadarsini, K. and Mohan, H. (2005). Formation of redox active nanoselenium on reactions of oxidizing free radicals with selenourea. Found Day, 273: 262-267.

54) Zhang, J. S., Gao, X. Y., Zhang, L. D. and Bao, Y. P. (2001). Biological effects of a nano red elemental selenium. Biofactors, 15: 27-38.

55) Mishra, B., Hassan, P. A., Priyadarsini, K. I. and Mohan, H. (2005). Reactions of biological oxidants with selenourea: formation of redox active nanoselenium. J. Phys. Chem. B. 109: 12718-12723.

56) Nyblom, H., Björnsson E., Simren, M., Aldenborg, F., Almer S, and Olsson, R. (2006). The AST/ALT ratio as an indicator of cirrhosis in patients with PBC. Liver Int. 26(7): 840-845.

57) Ekanem, J. T. and Yusuf, O. K. (2007). some liver function indices and blood parameters in T. bruceiinfected rats treated with honey. Biokemistry, 19(2): 81-86.

58) Al-Okbi, S. Y., Mohamed, D. A., Hamed, T. E., Esmail, R. SH. and Donya, S. M. (2014). Plant Food Extracts as a Source of Bioactive Compounds for Prevention of Cisplatin-Induced Kidney Dysfunction in Rats. Pol. J. Food. Nutr. Sci., 64(1): 49-57.

59) Olusola, A. O., Olusola, A, O., Bada, S. O. and Obi, F. O. (2012). Comparative study of the effect of $H$. sabdariffa calyx anthocyanins and ascorbate on 2,4-Dinitrophenylhydrazine-induced damage in rabbits. Am. J. Biochem., 2(2): 1-6.

60) Chen, H. M., Muramoto, K., Yamaushi, F. Fojimoto, K. and Nokihara, K. (1998). Antioxidant properties of histidine containing peptides designed from peptide fragment found in the digests of a soybean protein. J. Agric. Food Chem. 46: 49 - 53.

61) Brewer, M. S. (2011). Natural antioxidants: sources, compounds, mechanisms of action, and potential applications. Comp. Rev. Food Sci. Food Safety 10(4): 221-247. 
62) Lee, B. C., Jeong, Y. K. and Ryu, H. H. (1997). Antioxidantive effect of silymarin and silyb in purified from silybmarianum on oxidation of human low density lipoprotein by macrophage, Korean J. Microbiol. Biotech., 25: 286-292.

63) Palanivel, M. G., Rajkapoor, B., Kumar, R. S., Einstein, J. W., Kumar, E. P., Kumar, M. R., Kavitha, K., Kumar, M. P. and Jayakar, B. (2008). Hepatoprotective and Antioxidant Effect of Pisoniaaculeata $\mathrm{L}$. against $\mathrm{CCl}_{4}$ - Induced Hepatic Damage in Rats. Sci. Pharm., 76: 203-215.

64) Nichenametla, S. N., Taruscio, T. G., Barney, D. L. and Exon, J. H. (2006). A review of the effects and mechanisms of polyphenolics in cancer Crit. Rev. Food Sci. Nutr., 46: 161-183.

65) Wang, L.-S. and Stoner, G. D. (2008). Anthocyanins and their role in cancer prevention. Cancer Lett., 269: 281-290.

66) Ali, E. N., El-Sounbaty S. M. and Salem, F. M. (2013). Evaluation of selenium nanoparticles as potential chemopreventive agent against lung carcinoma. Intern. J. Pharmaceut. Biol. and Chem. Sci., 2(4): 38-46.
67) Afaq, F., Syed, D. N., Malik, A., Hadi, N., Sarfaraz, S., Kweon, M. H., Khan, N., Zaid, M. A. and Mukhtar, H. J. (2007). Delphinidin, an anthocyanidin in pigmented fruits and vegetables, protects human $\mathrm{HaCaT}$ keratinocytes and mouse skin against UVB-mediated oxidative stress and apoptosis, J. Invest. Dermatol., 127(1): 222-232.

68) Baud, V. and Karin, M. (2001). Signal Transduction by Tumor Necrosis Factor and its Relatives. Trends in Cell Biol., 11(9): 372-377.

69) Locksley, R. M., Killeen, N. and Lenardo, M. J. (2001). The TNF and TNF receptor superfamilies: integrating mammalian biology. Cell, 104(4): $487-$ 501.

70) Kuhlmann, W. D. and Peschke, P. (2006). Hepatic progenitor cells, stem cells, and AFP expression in models of liver injury. Int. J. Exp. Pathol., 87: 343359.

71) Seregni, E., Botti, C. and Bombardieri, E. (1995). Biochemical characteristics and clinical applications of alpha-fetoprotein isoforms. Anticancer Res., 15: 1491-1499. 